\title{
IMPLEMENTASI KEBIJAKAN DESENTRALISASI MENUJU MASYARAKAT MANDIRI DAN SEJAHTERA
}

\author{
I Wayan Sutrisna \\ Fakultas Ilmu Sosial dan Ilmu Politik Universitas Mahendradatta - Denpasar \\ e-mail: sutrisna76@yahoo.co.id
}

\begin{abstract}
Abstrak:Kebijakan Desentralisasi sesungguhnya dapat membawa bangsa ini ke dalam dua kemungkinan, yakni tantangan dan harapan. Artinya jika otonomi daerah dikelola dengan baik maka hal itu akan membawa masyarakat kepada kemajuan, kemakmuran yang dicita-citakan bersama. Hal ini diakibatkan oleh partisipasi publik akan mendapat ruang yang luas. Rakyat akan dapat menagih tanggung jawab kesejahteraan kepada kepala daerahnya. Ketika daya kritis dan kontrol ini semakin menguat maka pintu penyalahgunaan kekuasaan akan dapat dicegah kemunculannya. Akan tetapi sebaliknya apabila ini tidak dikelola dengan baik maka akan dapat mendatangkan petaka bagi masyarakat. Sebagai salah satu komponen pertanggungjawaban kepada publik, Pemerintah Daerah diharapkan dapat melakukan optimalisasi belanja yang dilakukan secara efektif dan efisien untuk mencapai tingkat kesejahteraan masyarakat yang lebih baik. Pemerintah melaksanan tiga fungsi utama, yaitu pertama fungsi alokasi, yakni pemerintah mengalokasikan dana sumber-sumber ekonomi dalam bentuk barang atau jasa pelayanan. Fungsi kedua yaitu fungsi distribusi, yakni fungsi pemerintah dalam usaha melaksanakan pemerataan pembangunan, pendapatan dan kekayaan, agar mengurangi tingkat kesenjangan. Fungsi yang ketiga yakni fungsi stabilisasi, yaitu fungsi pemerintah yang meliputi pertahanan keamanan, ekonomi dan moneter agar terpelihara kesempatan kerja yang luas, kestabilan harga dan pertumbuhan ekonomi. Perencanaan tidak akan dapat menghasilkan pembangunan secara baik sesuai dengan aspirasi masyarakat apabila tidak dapat mengoptimalkan partisipasi masyarakat dalam proses penyusunan rencana tersebut. Tanpa memanfaatkan partisipasi masyarakat secara baik dan terarah, perencanaan yang disusun tidak akan dapat disesuaikan dengan aspirasi dan keinginan masyarakat. Partisispasi masyarakat dalam penyusunan APBD harus diberikan ruang yang cukup agar keterlibatan masyarakat dalam proses pengelolaan anggaran daerah semakin maksimal sehingga akan dapat meningkatkan efisiensi dan efektivitas pembangunan.Kebijakan desentralisasi dengan pemberian hak otonom kepada pemerintah kabupaten/kota memberikan peluang kepada pemerintah daerah untuk merancang serta melaksanakan kebijakan yang memang diperlukan oleh masyarakat setempat. Otonomi daerah telah mendekatkan pemerintah kepada masyarakat dalam hal pelayanan serta pelibatan dalam seluruh kegiatan pembangunan. Pemerintah kabupaten/kota sebagai daerah otonom telah diberikan kewenangan lebih luas untuk menggali potensi daerah serta menyalurkan untuk kepentingan masyarakat secara maksimal dalam mewujudkan masyarakat yang sejahtera.
\end{abstract}

Kata kunci : desentralisasi, partisipasi dan kesejahtreraan 
Abstract: Decentralization policy can actually bring this nation into two possibilities, namely challenges and hopes. This means that if regional autonomy is well managed then it will bring society to progress, prosperity that is aspired together. This is caused by public participation will get a broad space. The people will be able to collect responsibility for welfare from their regional heads. When this critical power and control gets stronger the emergence of the door to abuse of power can be prevented. But on the contrary if this is not managed properly it will be able to bring disaster to the community. As one component of accountability to the public, the Regional Government is expected to be able to optimize spending carried out effectively and efficiently to achieve a better level of community welfare. The government carries out three main functions, namely the first function of allocation, namely the government allocates funds for economic resources in the form of goods or services. The second function is the distribution function, namely the function of the government in an effort to carry out equitable development, income and wealth, in order to reduce the level of inequality. The third function is the stabilization function, which is the function of the government which includes defense of security, economy and monetary to maintain broad employment opportunities, price stability and economic growth. Planning will not be able to produce development in accordance with the aspirations of the community if it cannot optimize community participation in the process of preparing the plan. Without utilizing community participation in a good and directed manner, the plans arranged cannot be adjusted to the aspirations and wishes of the community. Community participation in the preparation of the APBD must be given sufficient space so that community involvement in the process of managing the regional budget is maximized so that it can improve the efficiency and effectiveness of development. Decentralization policy by granting autonomous rights to district / city governments provides opportunities for regional governments to design and implement policies which is indeed needed by the local community. Regional autonomy has brought the government closer to the community in terms of services and involvement in all development activities. The district / city government as an autonomous region has been given wider authority to explore the potential of the region and to channel it to the interests of the community to its full potential in realizing a prosperous society.

\section{Keywords: decentralization, participation and welfare}

\section{A. Pengantar}

Salah satu kebijakan desentralisasi yang direalisasikan dengan pelaksanaan otonomi daerah mulai dilaksanakan secara luas diera reformasi, di mana telah mengubah tatanan pemerintahan yang sebelumnya bersifat sentralistik mengarah ke tatanan pemerintahan yang desentralisasi dengan memberikan kewenangan yang lebih luas kepada pemerintah daerah khusunya pemerintah kabupaten/kota. Pemberian hak otonomi kepada daerah bermakna bahwa
Pemerintah Pusat menyerahkan wewenang seluas-luasnya kepada Pemerintah Daerah untuk lebih dapat mengatur dan mengurus pemerintahannya di luar enam urusan yang masih diatur oleh pemerintah pusat, yakni: Politik luar negeri, Pertahanan, Keamanan, Yustisi, Moneter serta Fiskal Nasional, dan Agama.

Undang-Undang Nomor 23 tahun 2014 tentang Pemerintahan Daerah menyebutkan bahwa Otonomi Daerah adalah hak, wewenang, dan kewajiban daerah otonom untuk mengatur dan mengurus sendiri urusan pemerintahan dan kepentingan 
masyarakat setempat dalam sistem Negara Kesatuan Republik Indonesia (NKRI). Hak otonomi ini dapat dijadikan peluang bagi daerah dalam memberdayakan segala sumber daya yang ada untuk sebesarbesarnya kemakmuran rakyat di daerah masing-masing.Otonomi diberikan kepada pemerintah daerah dalam mengurus rumah tangganya termasuk memanfaatkan segala potensi yang ada demi tujuan dari visi misi kepala pemerintahan daerah yang berkuasa.

Keberhasilan Pemerintah Daerah dalam pelaksanaan Otonomi Daerah, salah satu tolok ukurnya adalah keberhasilan daerah dalam menggali, mengelola, mengarahkan, dan mengendalikan Anggaran Pendapatan dan Belanja Daerah (APBD) sesuai dengan arah kebijakan serta prioritas yang ditetapkan. Melalui belanja pemerintah dalam APBD tiap tahun yang diarahkan ke berbagai bidang pembangunan, program dan kegiatan sesuai dengan prioritas yang ditetapkan oleh daerah diharapkan mampu menstimulan perkembangan pembangunan di berbagai sektor.Selain itu, belanja tidak langsung yang sebagian besar dialokasikan untuk gaji dan upah pegawai serta biaya operasional dan pemeliharaan pada dasarnya diharapkan dapat meningkatkan pelayanan terhadap public atau masyarakat.

Pemerintahan daerah baik itu eksekutif dan legislatif, dituntut memiliki kemampuan dan pengetahuan memadai dalam perumusan perencanaan dan kebijakan strategis daerah, termasuk proses pengalokasian anggaran belanja daerah agar pelaksanaan kegiatan pelayanan publik bisa berjalan dengan baik,sekaligus pula dana yang dianggarkan untuk memberikan pelayanan dapat dikelola secara efektif dan efisien. Di dalam penyusunan anggaran dan perumusan kebijakan strategis harus selalu menggunakan pendekatan yang merupakan gabungan dari pendekatan dari bawah ke atas (bottom-up approach) serta pendekatan dari atas ke bawah (top-down approach). Dengan memperhatikan aspirasi dari masyarakat serta masukan-masukan dari seluruh komponen pemerintahan, pastilah pembangunan yang dilaksanakan dapat lebih dirasakan oleh semua lapisan masyarakat.

Para Kepala Daerah diminta harus dapat mendayagunakan potensi sumber daya yang ada secara optimal. Dengan berkurangnya tingkat ketergantungan pemerintah daerah terhadap pemerintah di pusat, meningkatnya profesionalisme aparatur pemerintah daerah, dan reformasi pengelolaan keuangan daerah, diharapkan ke depannya mampu mendukung terwujudnya otonomi daerah yang nyata, dinamis, serasi dan bertanggungjawab, serta memperkuat persatuan dan kesatuan bangsa dalam menyongsong era perekonomian global, dan dapat mewujudkan kesejahteraan masyarakat (Mardiasmo, 2018).

Kebijakan desentralisasi sesungguhnya dapat membawa bangsa ini ke dalam dua kemungkinan, tantangan dan harapan. Artinya jika otonomi daerah dikelola dengan baik, maka itu akan membawa masyarakat kepada kemajuan, kemakmuran yangdicitacitakan bersama.Masyarakat akan sejahtera, masyarakat miskin akan terus berkurang hingga mendekati angka nol atau daerah tanpa penduduk miskin. Hal ini diakibatkan oleh partisipasi publik akan mendapat ruang yang luas. Rakyat akan dapat menagih tanggung jawab kesejahteraan kepada kepala daerahnya. Ketika daya kritis dan kontrol ini semakin menguat di masyarakat, maka pintu 
penyalahgunaan kekuasaan akan lebih dapat dicegah kemunculannya. Namun sebaliknya,bilamana ini tidak dikelola secara

\section{B. Pengelolaan Keuangan Daerah}

Sebagai komponen pertanggungjawaban kepada khalayak publik, Pemerintah Daerah diharapkan dapat melakukan optimalisasi belanja yang dilakukan secara efektif dan efisien untuk mencapai tingkat kesejahteraan masyarakat yang lebih baik. Pemerintah pada hakikatnya mengembantiga fungsi utama, yakni pertama fungsi alokasi, di mana pemerintah mengalokasikandana sumber-sumber ekonomi dalam bentuk barang dan atau jasa pelayanan masyarakat. Fungsi kedua yaitu fungsi distribusi, yakni fungsi pihak pemerintah di dalam usahanyamelaksanakan pemerataan pembangunan, pendapatan, dan kekayaan agar mengurangi tingkat kesenjangan yang terjadi di dalam masyarakat.Fungsi yang ketiga yakni fungsi stabilisasi, yaitu fungsi pemerintahyang meliputi pertahanan keamanan, ekonomi, dan moneter supaya terpelihara kesempatan kerja yang lebih luas, kestabilan harga serta pertumbuhan ekonomi yang lebih memadai (Suhandak,2007)

Perencanaan anggaran yang lemah akibat kurang mampunya aparat perencana pembangunan serta diikuti oleh rendahnya penerimaandaerah akan justru menyulitkan pemerintah dalam memberikan pelayanan pada masyarakat. Hal ini dapat diperparah lagi dengan pengeluaran daerah yang terus meningkat. Apabila tidak disertai penentuan terkait skala prioritas dan besarnyaplafon anggaran akan mengakibatkan terjadinya baikmaka justru akan dapat mendatangkan petaka bagi masyarakat.

ketimpangan pada unit-unit kerja. Jika salah satuunit terjadi kekurangan pembiayaan, sementara unit yang lainnya bisa terjadi kelebihan pembiayaan, maka berdampak pada tingkat efisiensi sekaligus efektivitas pelayanan yang diberikan pada masyarakat. Masyarakat akan menilai bahwa pemerintah telah gagal dan pembangunan yang sudah dilaksanakan tidak berpihak kepada rakyat yang merupakan pemilik dari negeri ini.

Mardiasmo (2018) mengungkapkan bahwa perencanaan belanja oleh pemerintah bertujuan untuk memenuhi keinginan seluruh lapisan masyarakat. Proses dan pengalokasian anggaran harus berorientasi kepada kepentingan publik. Hal tersebut mengandung arti bahwa proses penyusunan anggaran hendaknya melibatkan banyak pihak mulai dari perencanaan sampai proses pelaksanaannya. Dari itu, lalu diharapkan belanja untuk kepentingan publik mendapat proporsi yang lebih besar daripada belanja untuk aparatur, karena itu belanja publik merupakan investasi pemerintah yang diharapkan meningkatkan kesejahteraan.Peran pemerintah mengatur pengeluarannya adalah instrumen penting mengendalikan perekonomian masyarakat.Cukup banyak ekonom berpendapat bahwa soal kenaikan pengeluaran pemerintah menjadi instrumen efektif untuk meningkatkan pertumbuhan ekonomi.Maka itu, pengeluaran pemerintah dalam bentuk belanja modal dapat memberi kontribusi cukup positif bagi pertumbuhan ekonomi yang berujung pada peningkatan kesejahteraan bagi masyarakat secara 
luas.Seperti pengelolaan keuangan daerah yang dilakukan di Provinsi Bali yang terdiri dari sembilan kabupaten/kota sebagai daerah otonom, fokus pengelolaan keuangannya diarahkan untuk kesejahteraan masyarakat.Pendapatan yang diperoleh dari berbagai sektor, utamanya adalah sektor pariwisata, itu digunakan untuk mewujudkan visimisi daerah tersebut. Berikut gambaran alokasi pendapatan dan belanja daerah dalam APBD kabupaten/kota di Bali pada tahun 2018.

\section{Gambar 1.1}

APBD Kabupaten/Kota di Bali tahun 2018

\section{(Dalam Triliun Rupiah)}

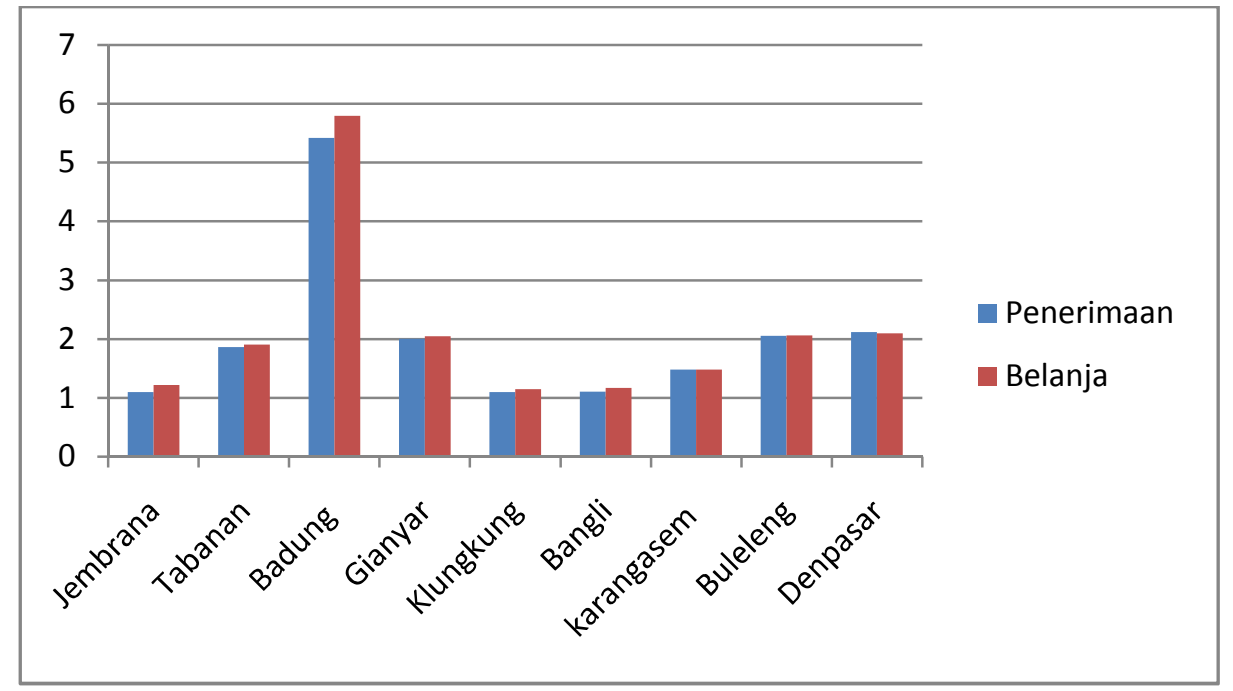

Sumber : BPS Prov. Bali tahun 2019

Pada Gambar 1.1 ditunjukkan bahwa dalam upayanya menyusun APBD beberapa Pemerintah Daerah di Bali membukukan pengeluaran yang dianggarkan melebihi penerimaan daerah itu sendiri.Maka secara umum penyusunan APBD kabupaten/kota di Bali, sudah dilakukan dengan baik yang

\section{Penyusunan Anggaran Berbasis Partisipasi Masyarakat}

Penganggaran sektor publik terkait dengan proses penentuan jumlah alokasi dana untuk setiap program dan aktivitas dalam satuan moneter. Anggaran merupakan artikulasi dari hasil perumusan strategi dan perencanaan strategi yang telah dibuat oleh ditandai dengan penilaian diberikan oleh Badan Pemeriksa Keuangan (BPK) RI yang menilai mayoritas pemerintah daerah telah mendapatpenilaian dengan predikat Wajar Tanpa Pengecualian (WTP).

suatu organisasi.Anggaran sektor publik dibuat untuk membantu menentukan tingkat kebutuhan masyarakat agar terjamin dengan layak dan berguna.Peningkatan kebijakan dalam pelaksanaan otonomi daerah dan desentralisasi fiskal, pemerintah daerah perlu menutupi kesenjangan fiskal dan meningkatkan kapasitas fiskal daerah.Hal yang perlu dilakukan adalah dengan mengoptimalkan manajemen PAD dan 
DAU, melalui pemanfaatan kedua sumber pendanaan tersebut pemerintah daerah memiliki kewenangan untuk mewujudkan prinsip transparansi, akuntabilitas publik dan value for money (Mardiasmo, 2018).

Potensi sumber daya manusia yang dimiliki Bangsa Indonesia sangat besar. Saat ini penduduk Indonesia mencapai lebih dari seperempat milyar orang, yang merupakan penopang proses pembangunan di negeri ini. Sumber daya manusia yang dimiliki ini apabila diarahkan dengan optimal akan mampu menjadi kekuatan utama pendukung pembangunan nasional. Namun keberadaan penduduk yang padat terkadang merupakan hambatan yang sangat mengganggu proses dari pembangunan. Penduduk yang acuh tak acuh dan tidak peduli dengan kehidupan berbangsa dan bernegara akan menjadi hambatan dalam pembangunan ini. Mereka tidak akan ikut melibatkan diri atau berpartisipasi ke dalam tahapan dan proses pembangunan sehingga apa yang menjadi tujuan pembangunan nasional tidak akan tercapai.

Partisipasi masyarakat dalam proses pembangunan merupakan kunci utama suksesnya pelaksanaaan pembangunan tersebut. Partisipasi masyarakat akan menempatkan masyarakat sebagai motor penggerak atau sebagai subyek pembangunan bukan hanya sebagai obyek atau penerima manfaat saja. Dengan Partisispasi ini membuat masyarakat akan merasa memiliki serta ikut bertanggungjawab terhadap setiap proses dan hasil-hasil pembangunan. Partisipasi masyarakat akan mengarah kepada pemberdayaan masyarakat karena melalui partisipasi dalam seluruh proses, masyarakat akan semakin berdaya dan mampu mengendalikan proses tersebut kearah pencapaian kesejahteraan masyarakat itu sendiri.

Sjafrisal (2017) menyebutkan bahwa perencanaan tidak akan dapat menghasilkan pembangunan secara baik sesuai dengan aspirasi masyarakat bilamana tidak dapat mengoptimalkan partisipasi masyarakat dalam proses penyusunan rencana tersebut. Tanpa memanfaatkan partisipasi masyarakat secara baik dan terarah, perencanaan yang disusun tidak akan dapat disesuaikan dengan aspirasi dan keinginan masyarakat. Disamping itu, tanpa partisipasi masyarakat sulit pula diharapkan akan mematuhi dan menjaga pelaksanaan rencana yang telah dibuat. Bahkan tidak jarang pula terjadi masyarakat tidak memanfaatkan sepenuhnya apa yang telah dibangun oleh pemerintah.

Masyarakat yang partisipatif dalam proses pembangunan mengandung arti bahwa masyarakat berinisiatif memulai proses kegiatan untuk perubahan kearah yang lebih baik. Pertisipasi masyarakat hanya bisa terjadi apabila warganya ikut aktif.Jumlah penduduk yang banyak serta diimbangi dengan partisipasi yang tinggi membuat penduduk menjadi kekuatan besar dalam segala kegiatan berbangsa dan bernegara. Hal ini akan menjadi modal dan kekuatan untuk mensukseskan pembangunan nasional.

Partisipasi masyarakat dalam proses pembangunan di Indonesia pada umumnya saat ini masih sangat rendah. Masyarakat masih enggan untuk terlibat secara langgsung dalam seluruh proses baik itu perencanaan, pelaksanaan maupun evaluasi pembangunan yang dilaksanakan oleh 
pemerintah. Rendahnya partisipasi ini akibat dari kebijakan pemerintah yang masih kurang dalam memberikan ruang bagi setiap warga Negara untuk berpartisipasi dalam pembangunan. Pelaksanaan Musyawarah perencanaan Pembangunan (Musrenbang) mulai pada tingkat desa hingga nasional dianggap oleh sebagaian masyarakat hanya proses serimonial belaka. Musrenbang yang dilaksanakan selama ini hanya melibatkan segelintir elit dalam masyarakat saja dan tidak memberikan ruang yang cukup kepada mayoritas masyarakat.

\section{Mewujudkan Masyarakat Sejahtera di era Otonomi Daerah}

Otonomi Daerah dan desentralisasi fiskal telah memberikan konsekuensi pada pola pembagian dan hubungan kewenangan antara pemerintah pusat dan pemerintah daerah, serta hubungan keuangan antara pemerintah pusat dan pemerintah daerah.Terjadinya pelimpahan kewenangan dalam menjalankan urusan dari pemerintah pusat kepada pemerintah daerah dalam rangka mendekatkan pelayanan untuk masyarakat dan mempercepat kesejahteraan. Pelimpahan kewenangan itu diikuti dengan penyerahan sumber pendanaan berupa penyerahan basis perpajakan maupun bantuan pendanaan melalui mekanisme transfer ke daerah (Mardiasmo 2018).

Menurut Abimanyu dan Megantara (2009),desentralisasi fiskal akan mampu meningkatkan pertumbuhan ekonomi dan kesejahteraan suatu masyarakat, karena itu pemerintah sub nasional/pemerintah daerah akan lebih efisien dalam produksi dan rangka penyediaan barang-barang publik. Pengambilan keputusan pada level
Masyarakat yang partisipatif sangat dibutuhkan dalam proses pemerintahan dan pembangunan. United Nation Development Program (UNDP),juga telah memasukkan partisipasi masyarakat ke dalam salah satu indikator atau karakteristik pemerintahan yang baik (good governance).Hal dimaksud mengandung arti bahwa makin tinggi tingkat partisipasi suatu masyarakat di dalam proses pemerintahan dan rencana pembangunan, menunjukkan bahwa pemerintahan yang sedang berkuasa telah melaksanakan proses pemerintahan yang baik.

pemerintah lokal akan lebih didengarkan untuk menganekaragamkan pilihan lokal dan lebih berguna bagi efisensi alokasi.

Bahl (2000) mengemukakan dalam aturan yang keduabelas, bahwa desentralisasi harus memacu adanya persaingan di antara berbagai pemerintah lokal untuk menjadi pemenang (there must be a champion for fiscal decentralization). Hal ini dapat dilihat dari semakin baiknya pelayanan publik. Pemerintah lokal berlomba-lomba untuk memahami benar dan memberikan apa yang terbaik yang dibutuhkan oleh masyarakatnya, perubahan struktur ekonomi masyarakat dengan peran masyarakat yang makin besar meningkatkan kesejahteraan rakyat, partisipasi rakyat setempat dalam pemerintahan dan lain-lain.

Kesejahteraan masyarakat merupakan upaya nyata pemenuhan kebutuhan hak-hak dasar masyarakat. Dalam berbagai pedekatan pembangunan dewasa ini, hakhak dasar tersebut diklasifikasi dalam sepuluh jenis, meliputi kecukupan dan mutu pangan; akses dan mutu kesehatan; akses dan mutu pendidikan; kesempatan kerja dan 
kesempatan berusaha; akses layanan perumahan dan sanitasi; akses terhadap air bersih; kapasitas kepemilikan dan penguasaan tanah; kondisi lingkungan hidup dan sumberdaya alam yang baik serta akses masyarakat terhadap sumberdaya alam yang memadai; jaminan rasa aman; dan berkembangnya partisipasi masyarakat. Indikator kesejahteraan masyarakat yang disusun oleh UNDP dikenal dengan Human Development Index (HDI) atau Indeks Pembangunan Manusia (IPM).Pengukuran kesejahteraan melalui IPM tersebut, saat ini dianggap memberikan kemajuan besar dalam pengukuran indikator keberhasilan pembangunan. Pengukuran indikator IPM, sebagaimanan laporan UNDP mendefiniskan pengukuran IPM melalui pencapaian keseluruhan dari suatu negara dalam tiga dimensi dasar pembangunan manusia, yaitu lamanya hidup, pengetahuan dan standar hidup layak (UNDP, 1995).

Pelaksanaan kebijakan desentralisasi dengan pemberian hak otonom kepada pemerintah kabupaten/kota telah memberikan peluang kepada pemerintah otonom untuk merancang serta melaksanakan kebijakan yang memang diperlukan oleh masyarakat setempat. Otonomi daerah telah mendekatkan pemerintah kepada masyarakat dalam hal pelayanan serta pelibatan dalam seluruh kegiatan pembangunan. Pemerintah kabupaten/kota sebagai daerah otonom telah diberikan kewenangan lebih luas untuk menggali potensi daerah serta menyalurkan untuk kepentingan masyarakat secara maksimal. Implementasi good governance dalam pelaksanaan otonomi daerah akan mampu mewujudkan pemerintahan yang kuat serta masyarakat yang sejahtera.

\section{E. Penutup}

Desentralisasi yang secara penuh dilaksankan mulai era reformasi telah memberi kewenangan kepada pemerintah kabupaten/kota dalam melakukan ekselerasi pembangunan menuju ke arah peningkatan kesejahteraan masyarakat. Pemberian hak otonomi harus mampu digunakan dalam pengelolaan potensi yang dimiliki oleh masing-masing daerah untuk sebesarbesarnya kemakmuran rakyat. Para kepala daerah dituntut memiliki keselarasan keinginan dalam proses pembangunan dengan mayoritas masyarakat yang ada di daerah tersebut. Hak otonomi ini harus mampu dimanfaatkan oleh pemerintah daerah dalam memberikan pelayanan yang maksimal khususnya dalam proses pembangunan,

Di era oronomi daerah ini, pengelolaan keuangan daerah menjadi hal yang sangat sentral dalam mewujudkan kesejahteraan masyarakat. Anggaran yang dimiliki yang sebagaian besar bersumber dari pendapatan asli daerah harus dikelola dengan penggunaan anggaran yang sebagian besar digunakan untuk belanja langsung yang menyentuh kepada kepentingan masyarakat. Penmgelolaan anggaran ini merupakan tolak ukur keberhasilan pemerintah daerah dalam pelaksanaan otonomi daerah.

Untuk mewujudkan good governance dalam pelaksanaan otonomi daerah, partisispasi masyarakat dalam penyusunan APBD harus diberikan ruang yang cukup agar keterlibatan masyarakat dalam proses pengelolaan anggaran daerah semakin 
maksimal sehingga akan bisa meningkatkan efisiensi dan efektivitas pembangunan yang dilaksanakan. Hal dimaksud terjadi karena penyelenggaraan pembangunan akan lebih bisa dilakukan secara transparan, akuntabel, bermoral, dan beretika yang berorientasi pada kepentingan rakyat banyak.Seluruh SDM dimiliki diberikan ruang yang sama dalam keterlibatan mereka pada pelaksanaan pembangunan yang akan dirancang oleh pemerintah daerah.

Pengelolaan potensi daerah yang dilakukan secara otonom oleh pemerintah daerah membuat masyarakat lebih tertarik untuk melibatkan diri dalam seluruh

\section{Daftar Pustaka}

Abimanyu, A. dan Megantara, A. 2009.Era Baru Kebijakan Fiskal; Pemikiran, Konsep dan Implementasi, Penerbit Kompas, Jakarta: Penerbit Kompas.

Bahl, R. W.,2000. China : Evaluating the impact of Intergovemmental Fiscal reform dalam Fiscal Decentralization in Developing Countries. Edited by Richard M. Bird and Francois Vaillancourt, United Kingdom : Cambridge Univercity Press.

Kaho, J.R. 1997. Prospek otonomi di Negara Republik Indonesia. Jakarta. PT Raja Grafido persada.

Khusaini, Muhammad. 2006. Ekonomi Publik: Desentralisasi Fiskal dan Pembangunan Daerah. Malang. BPFE UNIBRAW. prosesnya. Pelaksanaan pembangunan yang dilaksanakan dengan pola partisipatif yakni pola pembangunan yang mulai dari proses perencanaan sudah melibatkan seluruh komponen masyarakat secara partisipatif diyakini akan mampu mewujudkan pertumbuhan ekonomi yang tinggi dan berkualitas.Otonomi daerah yang dilaksanakan dengan prinsip-prinsip good governance diyakini akan mampu mencapai tujuan pembangunan secara efektif dan efisien yang berujung kepada peningkatan kesejahteraan masyarakat secara umum

Kunarjo. 1996. Perencanaan dan Pembiayaan Pembangunan, edisi ketiga. Jakarta. UI-Press.

Mandica, Notrida. 2001. Desentralisasi, Anggaran daerah, dan Akuntabilitas Publik. Jakarta. Juni Nomor 338 tahun Ke-36, PT Kompas Media.

Mardiasmo. 2018. Otonomi dan Manajemen Keuangan daerah. Yogyakarta. ANDI

Rahayu, Ani Sri. 2014. Pengantar Kebijakan Fiskal. Jakarta. Bumi Aksara.

Santosa, Pandji.2017. Administrasi Publik; Teori dan Aplikasi Good Governance. Bandung. Refika Aditama.

Sjafrizal.2017. Perencanaan Pembangunan Daerah dalam era Otonomi.Depok. Rajawali Pers.

Suhandak dan Nugroho,Trilaksono. 2007. Paradigma baru pengelolaan 


keuangan daerah dalam
penyusunan APBD di era
Otonomi. Malang. FIA Unibraw.

Suprayitno, Bambang. 2017. Ekonomi Publik, Konsep dan Implemetasi Kebijakan, Yogyakarta. UPP STIM YKPN

Undang-Undang Republik Indonesia Nomor 23 tahun 2014 tentang Pemerintahan Daerah.

Undang-Undang Republik Indonesia Nomor 33 tahun 2004 tentang Perimbangan Keuangan antara Pemerintah Pusat dan Pemerintah Daerah.

UNDP. 1995. "Human Development Report" United Nations Development Programme. New York 